\title{
PReS-FINAL-2149: Interaction of PTPN2 and vitamin $D$ GC sequence variants and risk of juvenile idiopathic arthritis
}

\author{
JA Ellis ${ }^{1^{*}}$, KJ Scurrah ${ }^{2}$, RA Chavez ${ }^{1}$, AL Ponsonby ${ }^{3}$, A Pezic ${ }^{3}$, RC Allen ${ }^{4,5}$, JD Akikusa ${ }^{4,5}$, JE Munro ${ }^{4,5}$ \\ From 20th Pediatric Rheumatology European Society (PReS) Congress \\ Ljubljana, Slovenia. 25-29 September 2013
}

\section{Introduction}

The causes of autoimmune diseases, including juvenile idiopathic arthritis (JIA) are presumed to involve the interplay of genes and environment. Vitamin D interacts with genes via vitamin $\mathrm{D}$ response elements (vdres). The gene PTPN2, associated with various autoimmune diseases including JIA, carries a VDRE and is regulated by vitamin D. Recently, an interaction between PTPN2 and VDR (vitamin D receptor gene) was reported for type 1 diabetes, such that disease association with VDR differed by PTPN2 genotype.

\section{Objectives}

We aimed to detect interaction of PTPN2 with $V D R$, or with other vitamin D pathway genes $(G C, C Y P 2 R 1$, DHCR7, CYP24A1), in determining risk of JIA.

\section{Methods}

15 snps were genotyped in 324 JIA cases and 568 controls from the childhood Arthritis Risk factor Identification study (CLARITY) in Melbourne Australia. We looked for association of each SNP with JIA in the entire dataset, and performed sensitivity analyses restricting to Caucasians (case $\mathrm{n}=204$, control $\mathrm{n}=348$ ) to control for population stratification. We then looked for interaction of PTPN2 with vitamin $\mathrm{D}$ genes in determining JIA risk on both a multiplicative and additive scale. Multiplicative interaction was assessed by the use of a product term in logistic regression. Additive interaction was assessed by calculating the Relative Excess Risk due to Interaction (RERI), along with $95 \%$ confidence intervals and $p$ value using bootstrapping and permutation procedures respectively.

${ }^{1}$ Genes, Environment \& Complex Disease, Murdoch Childrens Research Institute, Parkville, Victoria, Australia

Full list of author information is available at the end of the article

\section{Results}

No snps were individually associated with JIA, except $G C$ rs1155563 which was marginally associated in the entire dataset ( $\mathrm{p}=0.023)$, but not in Caucasians. A multiplicative interaction was observed between PTPN2 and VDR in the entire dataset ( $\mathrm{p}=0.016)$, but not in Caucasians. However, multiplicative interactions were observed between PTPN2 and $G C$ which were evident overall and particularly among Caucasians (eg PTPN2 rs254151 and GC rs1155563: $p=0.0009$ ). On an additive scale, possibly better reflecting biological interaction, we observed a RERI that deviated significantly from zero, providing further evidence of a negative interaction (PTPN2 rs254151 and GC rs1155563: RERI $=-1.09 ; 95 \%$ CI $-2.08,-0.38 ; \mathrm{p}=0.0004)$.

\section{Conclusion}

We have identified interaction between PTPN2 and GC in determining risk of JIA in Caucasian children recruited to CLARITY. The evidence of interaction also on an additive scale adds biological plausibility. The data is consistent with the notion that PTPN2 is responsive to vitamin D, since $\mathrm{GC}$ variants alter the delivery of vitamin $\mathrm{D}$ to target cells, and rs1155563 is associated with circulating vitamin D levels. While our findings await replication, they do support the concept that vitamin D may be an environmental factor that interacts with immune-related genes in JIA.

\section{Disclosure of interest}

None declared.

\section{Authors' details}

${ }_{1}^{1}$ Genes, Environment \& Complex Disease, Murdoch Childrens Research Institute, Parkville, Victoria, Australia. ${ }^{2}$ Physiology, University of Melbourne, University of Melbourne, Australia. ${ }^{3}$ Environmental \& Genetic Epidemiology Research, Australia. ${ }^{4}$ Arthritis Research, Murdoch Childrens Research Institute, 
Published: 5 December 2013

doi:10.1186/1546-0096-11-S2-P161

Cite this article as: Ellis et al:: PReS-FINAL-2149: Interaction of PTPN2 and vitamin D GC sequence variants and risk of juvenile idiopathic arthritis. Pediatric Rheumatology 2013 11(Suppl 2):P161.

Submit your next manuscript to BioMed Central and take full advantage of:

- Convenient online submission

- Thorough peer review

- No space constraints or color figure charges

- Immediate publication on acceptance

- Inclusion in PubMed, CAS, Scopus and Google Scholar

- Research which is freely available for redistribution 